\title{
EVALUASI PURNA HUNI PASAR TRADISIONAL KOTA PONTIANAK DITINJAU DARI ASPEK PERILAKU (STUDI KASUS: PASAR KEMUNING DAN PASAR DAHLIA)
}

\author{
M. Nurhamsyah \\ Jurusan/Program Studi Arsitektur, Fakultas Teknik, Universitas Tanjungpura \\ Jln. Prof. H. Hadari Nawawi, Pontianak, e-mail: nurhamsyah @teknik.untan.ac.id \\ M. Ridha Alhamdhani \\ Jurusan/Program Studi Arsitektur, Fakultas Teknik, Universitas Tanjungpura \\ Jln. Prof. H. Hadari Nawawi, Pontianak, e-mail: Mridhaalhamdani@teknik.untan.ac.id

\section{Rudiyono} \\ Jurusan/Program Studi Arsitektur, Fakultas Teknik, Universitas Tanjungpura \\ Jln. Prof. H. Hadari Nawawi, Pontianak, e-mail: rudiyono@teknik.untan.ac.id
}

\begin{abstract}
Traditional market arrangement is a work program that has been carried out by the Pontianak City Government. This policy is an effort to maintain the existence of traditional markets as one of the economic drivers for middle and lower middle income people. Traditional market structuring programs that have been implemented include the arrangement of Pasar Kemuning and Pasar Dahlia which are the selected objects in this study. In line with the functioning of this market, there are still several obstacles, including not all of the kiosks / stalls used to function, changes in the capacity of lapak users, and changes in the position of lapak spaces from the initial planning. This study aims to evaluate the building by looking at the scope of the market user behavior problems. The method used is the Post-Occupancy Evaluation (EPH) from the aspect of behavior which includes human factors as building users, circulation access, movement node points, territorial area and orientation. This study uses 2 (two) elements of data, namely literature data (standards) and field observation data (quantitative data). Literature data is used to see the suitability of building designs with predetermined standards. Field observation data is primary data in the form of observations of market user behavior using the person center mapping method.The two data are then analyzed to see the condition of building performance based on existing standards and aspects of market user behavior so that it can describe the level of performance quality and function of the market building. The results showed that there were some similarities in the quality of building performance from the aspect of behavior between the two markets, especially on circulation access, node points, territories and orientation, although there were differences and certain characteristics between the two markets.
\end{abstract}

Keywords: market, post-occupancy evaluation, and behavioral aspects

\begin{abstract}
Abstrak: Penataan pasar tradisional merupakan program kerja yang telah dijalankan Pemerintah Kota Pontianak. Kebijakan tersebut sebagai upaya untuk mempertahankan eksistensi pasar tradisional sebagai salah satu penggerak ekonomi bagi masyarakat berpenghasilan menengah dan menengah kebawah. Program penataan pasar tradisional yang telah diwujudkan antara lain penataan Pasar Kemuning dan Pasar Dahlia yang merupakan objek terpilih dalam penelitian ini. Sejalan berfungsinya pasar tersebut masih terdapat beberapa kendala, antara lain tidak semua kios/lapak yang digunakan dapat berfungsi, perubahan kapasitas pengguna lapak, dan perubahan posisi ruang lapak dari perencanaan awal. Penelitian ini bertujuan untuk mengevaluasi bangunan dengan melihat lingkup permasalahan perilaku pengguna pasar. Metode yang digunakan adalah Evaluasi Purna Huni (EPH) dari aspek perilaku yang mencakup faktor manusia sebagai pengguna bangunan, akses sirkulasi, titik simpul pergerakan, area teritori dan orientasi. Penelitian ini menggunakan 2 (dua) unsur data yaitu data literatur (standar), dan data observasi lapangan (data kuantitatif). Data literatur digunakan untuk melihat kesesuaian desain bangunan dengan standar yang telah ditetapkan. Data observasi lapangan adalah data primer berupa hasil pengamatan perilaku pengguna pasar dengan metode person center mapping. Kedua data tersebut kemudian dianalisis untuk melihat kondisi performa bangunan berdasarkan standar yang ada dan aspek perilaku pengguna pasar sehingga dapat menggambarkan tingkat kualitas performansi dan fungsi bangunan pasar. Hasil penelitian menunjukkan terdapat beberapa kesamaan kualitas perfomansi bangunan dari aspek perilaku antara kedua pasar terutama pada akses sirkulasi, titik simpul, teritori dan orientasi, meskipun diantara keduanya terdapat perbedaan dan ciri khas tertentu berdasarkan lokasi.
\end{abstract}

Kata kunci: pasar, evaluasi purna huni, dan aspek perilaku 


\section{PENDAHULUAN}

Penataan pasar tradisional merupakan program kerja yang telah dijalankan Pemerintah Kota Pontianak dalam upaya untuk mempertahankan eksistensi pasar tradisional sebagai salah satu penggerak ekonomi bagi masyarakat, khususnya bagi masyarakat berpenghasilan menengah dan menengah kebawah. Program penataan pasar tradisional yang telah diwujudkan oleh Pemerintah Kota Pontianak diantaranya adalah Pasar Kemuning dan Pasar Dahlia.

Sejalan dengan berfungsinya pasar-pasar tersebut, ditemukan fenomena belum optimalnya fungsi pasar secara keseluruhan. Fenomena ini cenderung berulang dan menjadi permasalahan yang sama di pasar-pasar tersebut. Permasalahan tersebut antara lain belum berfungsinya kios-kios yang berada di lantai dua bangunan. Kios-kios tersebut terlihat sepi dan tidak digunakan untuk usaha. Fenomena ini terjadi pada kedua pasar yang menjadi objek penelitian ini yaitu : Pasar Kemuning dan Pasar Dahlia yang telah ditata dan berfungsi lebih dari 5 tahun. Permasalahan lainnya adalah kapasitas pengguna yang meningkat sehingga menimbulkan ruang dan posisi baru untuk usaha dan telah berubah dari fungsi atau perencanaan sebelumnya, kemudian munculnya titik simpul pergerakan pada zona tertentu yang mengakibatkan kepadatan, munculnya area parkir yang tidak direncanakan sebelumnya, serta kondisi pasar yang sulit untuk diakses dan tidak nyaman bagi yang berkebutuhan khusus.

Semua permasalahan yang muncul ini akan mempengaruhi tingkat kualitas perfomansi bangunan, untuk itu diperlukan suatu metode pengukuran kinerja performansi bangunan melalui metode Evaluasi Purna Huni (EPH) atau Post Occupancy Evaluation (POE). Metode ini adalah evaluasi yang terukur untuk mengetahui performansi bangunan dan dampaknya bagi pengguna dan lingkungannya setelah dihuni atau dipergunakan. Berdasarkan permasalahan yang terjadi pada kasus pasar yang menjadi objek penelitian, maka evaluasi difokuskan pada aspek perilaku dikarenakan fenomena permasalahan yang ditemui dalam penataan pasar tradisional adalah permasalahan terhadap perilaku pengguna baik penjual atau pembeli, selain dari faktor teknikal dan faktor fungsional bangunan. Aspek perilaku mencakup faktor manusia, kegiatan yang berlangsung, ruang gerak dan fleksibilitas, akses sirkulasi, titik simpul pergerakan, area teritori kegiatan, dan orientasi ke bangunan.
Hasil evaluasi ini nantinya sebagai upaya perbaikan atau optimalisasi peningkatan kualitas performansi fungsi bangunan pasar dan lingkungan sekitarnya, dalam waktu jangka pendek, menengah dan jangka panjang (pengembangan di masa mendatang).

\section{KAJIAN LITERATUR}

Menurut Keputusan Menteri Perindustrian dan Perdagangan Nomor 23/MPP/KEP/1/1998 pasar dikelompokkan menurut kelas pelayanannya terbagi menjadi pasar tradisional dan pasar modern, sedangkan menurut sifat pendistribusiannya dapat dikelompokkan menjadi pasar eceran dan pasar kulakan/grosir. Pasar tradisional diartikan sebagai pasar yang oleh pemerintah, swasta, koperasi, atau swadaya masyarakat dengan tempat usaha berupa toko, kios, los, dan tenda yang dikelola pedagang kecil dan menengah atau koperasi dengan skala usaha kecil dan modal kecil dengan proses jual beli melalui tawar menawar.

Pasar tradisional juga didefinisikan sebagai pasar yang bentuk bangunannya relatif sederhana dengan suasana yang relatif kurang memadai, termasuk dalam kebersihan dan penerangan. Barang-barang yang diperdagangkan juga berupa barang kebutuhan sehari-hari dengan mutu bukan menjadi prioritas atau perhatian. (Departemen Koperasi dan Usaha Kecil dan Menengah dalam Sukriswanto, 2012)

Evaluasi Purna Huni (EPH) atau disebut juga Post Occupancy Evaluation (POE) adalah sebuah metoda standar akademis yang digunakan oleh kalangan ilmiah dan konsultan di bidang kawasan binaan dan arsitektur untuk mengetahui sejauh mana hasil sebuah karya arsitektur dan lingkungan binaan terbangun mempunyai dampak pada penghuninya.

Menurut Zimring dan Reizenstein (1980) evaluasi purna huni didefinisikan sebagai pengujian efektivitas sebuah lingkungan binaan bagi kebutuhan manusia, baik pengujian efektivitas bangunannya sendiri maupun efektivitas programnya terhadap kebutuhan pengguna.

Evaluasi Purna Huni (EPH) / Post Occupancy Evaluation (POE) menurut Vischer (2002) dalam Khalil (2008), adalah suatu metode evaluasi yang digunakan untuk menemukan kegagalan atau kesalahan kriteria desain dan konstruksi, mengukur kinerja aset dan manajemen fasilitas, mengefisiensikan biaya siklus hidup fasilitas aset dengan mengidentifikasi kesalahan desain yang 
dapat menyebabkan peningkatan pemeliharaan dan biaya operasional, memperjelas tujuan desain dan meningkatkan kinerja bangunan. Dengan melakukan evaluasi purna huni, menurut Snyder (1984) keputusan-keputusan yang diambil dimasa yang akan datang menjadi lebih baik karena akibat-akibat dari keputusan di masa lalu dapat diketahui (baik hukum maupun metode).

Tujuan dari Evaluasi Purna Huni (EPH) / POE adalah mengevaluasi suatu bangunan yang telah difungsikan secara sistematik dan cermat untuk mengetahui performansi tingkat keberhasilan dan kekurangan dalam bangunan yang berpengaruh pada penguhuni atau penggunanya, dan kemudian untuk memberikan masukan perbaikan bagi desain bangunaan tersebut kedepannya.

Menurut Snyder (1984), evaluasi purna huni terutama terfokus pada tiga faktor elemen evaluasi yaitu evaluasi teknis, evaluasi fungsional, dan evaluasi perilaku. Evaluasi perilaku merupakan evaluasi yang menekankan pada hubungan antara perilaku dan lingkungan fisik. Palm, P (2007) dalam Chikezie (2013). Perilaku manusia merupakan aspek sosial dan psikologis dari tingkat kepuasan penghuni/pengguna bangunan. Aspek ini menghubungkan pemakai dengan lingkungan fisiknya; yang meliputi privasi dan interaksi penghuni, persepsi lingkungan, rasa kepemilikan, pemahaman desain bangunan, kognisi penghuni, dan orientasi lingkungan.

Arsitektur perilaku adalah hubungan timbal balik antara arsitektur, lingkungan dan perilaku manusia. Lingkungan tempat tinggal akan mempengaruhi perilaku manusia dan sebaliknya perilaku manusia akan membentuk lingkungannya. Dalam pendekatan studi perilaku, lingkungan dalam skala kecil adalah arsitektur dan dalam skala besar merupakan kawasan atau kota sedangkan perilaku manusia diartikan sebagai aktivitas dan perilaku pengguna / pelaku (Haryadi dan Bakti Setiawan, 1995).

Evaluasi bangunan dalam kajian arsitektur perilaku bertujuan mewujudkan suatu lingkungan binaan yang lebih baik dan bermakna dimana terjadinya hubungan yang positif antara pengguna, bangunan, dan lingkungan. Disamping itu juga bertujuan untuk meningkatkan kualitas lingkungan yang lebih baik dengan mengurangi dampak-dampak kerusakan lingkungan, serta sebagai acuan dan arahan bagi proses perencanaan, pengembangan, perancangan arsitektur dan kota yang lebih sistematis dengan melihat interaksi antara manusia dan lingkungan.

Dalam studi tentang hubungan arsitektur lingkungan dan perilaku dalam kaitannya dengan tata ruang, perilaku dioperasionalisasikan sebagai kegiatan manusia yang membutuhkan setting (tata ruang yang terkait dengan kegiatan) atau wadah kegiatan yang berupa ruang. Berbagai kegiatan manusia saling berkaitan dalam satu sistem kegiatan, dengan demikian wadah-wadah berbagai kegiatan tersebut juga terkait dalam satu sistem pula. Keterkaitan wadah-wadah kegiatan inilah yang membentuk tata ruang yang merupakan bagian dari bentuk arsitektur (Haryadi, 1995:7-8).

Ruang adalah sistem lingkungan binaan terkecil yang sangat penting, terutama karena sebagian besar waktu manusia modern saat ini banyak dihabiskan di dalamnya sebagai tempat aktivitas dan kegiatan. Dalam kajian arsitektur lingkungan dan perilaku, ruang diartikan sebagai suatu petak yang dibatasi oleh bidang permanen atau tidak permanen, oleh dinding, lantai, atap, atau penanda yang tak permanen. Dalam kaitannya dengan manusia, hal paling penting dari pengaruh ruang terhadap perilaku manusia adalah fungsi atau pemakaian ruang tersebut.

Menurut Friedman, dkk (1978) dalam Laurens (2004:156-157), setting adalah projek yang akan dievaluasi dengan aspek karakteristik sosial dan fisiknya, seperti kualitas dari keseluruhan desain dengan nilai simbolik bagi penggunan dan orang lain, kondisi elemen permanen atau temporer termasuk pemeliharaan, tujuan organisasi, kebutuhan, interaksi manusia, dan pola komunikasi. Lebih lanjut Laurens menjelaskan bahwa setting meliputi bangunan dan lingkungan ruang luar yang dirancang dan juga organisasi yang akan menempati lingkungan binaan tersebut. Menurut Haryadi (1995:55), ada 2 macam ruang yang dapat mempengaruhi perilaku yaitu :

1. Ruang yang dirancang untuk memenuhi suatu fungsi atau tujuan tertentu.

2. Ruang yang dirancang untuk memenuhi fungsi yang fleksibel.

Masing-masing perancangan fisik ruang tersebut mempunyai variable independent yang berpengaruh terhadap perilaku pengguna.

\section{METODE PENELITIAN}

Penelitian ini merupakan penelitian deduktifeksploratif yang dilakukan di lapangan (field research). Dalam penelitian ini menggunakan metode Evaluasi Purna Huni (EPH) atau Post Occupancy Evaluation (POE) dari aspek perilaku. EPH aspek perilaku merupakan suatu langkah 
evaluasi terhadap bangunan guna mengetahui kualitas bangunan yang telah digunakan, berdasarkan faktor perilaku manusia, persepsi dan kebutuhan pengguna. Model EPH/POE yang dipilih dalam penelitian ini adalah model tingkatan Investigative, dimana tingkatan evaluasi model ini memerlukan waktu yang cukup lama di lapangan, lebih mensyaratkan teknik pengumpulan data dan analisa yang baik, memakai kriteria-kriteria penelitian yang secara obyektif dan eksplisit, dan dengan bentuk kegiatan yaitu penilaian berdasarkan literatur (teori) dan perbandingan dengan bangunan atau fasilitas sejenis.

Tahapan proses penelitian yang dilakukan adalah sebagai berikut :

1. Mengidentifikasi dan melakukan studi pendahuluan terhadap kasus pasar terpilih.

2. Mendokumentasikan dan mendiskripsikan kondisi faktual bangunan pasar ditinjau dari aspek perilaku.

3. Melakukan pengumpulan data dengan metode :

a) Place - centered mapping $\rightarrow$ memetakan amatan setting atau ruang, tempat berlangsungnya aktifitas atau kegiatan oleh pengguna atau pengunjung dalam memfungsikan bangunan pada waktu tertentu.

b) Person-centered mapping $\rightarrow$ melakukan pengamatan terhadap subjek atau pengguna secara rinci dengan memetakan pergerakan pengguna, aktivitas pengguna dalam setting ruang tertentu dengan waktu yang rinci.

4. Mendokumentasikan kondisi objek penelitian, pengamatan terhadap pengguna pasar.

5. Melakukan evaluasi terhadap aspek perilaku dari masing-masing objek penelitian;

6. Menganalisa data dari hasil evaluasi pemetaan pada kedua objek penelitian berdasarkan teori atau standar yang ada dan berlaku, untuk kemudian dibandingkan hasil analisanya.

7. Menyimpulkan hasil evaluasi untuk memberi gambaran kualitas bangunan dan indikasi keberhasilan desain objek penelitian.

8. Memberikan usulan terhadap hasil evaluasi yang telah dilakukan.

\section{HASIL DAN PEMBAHASAN}

\section{Pasar Kemuning}

Bangunan pasar ini terletak di Jalan Prof. Muh Yamin, tepatnya kurang lebih 50 meter dari titik awal jalan. Pengunjung dapat langsung mengenali lokasi pasar tersebut ditandai dengan aktivitas yang dilakukan pada pagi hari, sehingga bangunan tersebut cukup menjadi area yang ramai dengan kegiatan membeli kebutuhan sehari-hari.

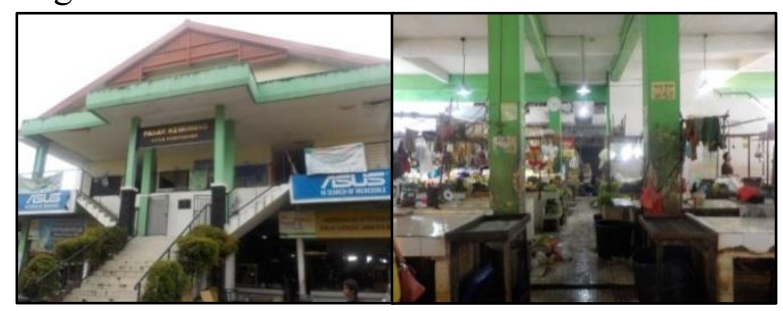

Gambar 1. Suasana Pasar Kemuning

Berdasarkan hasil survei data yang di dapatkan di lapangan, terdapat beberapa jalur akses masuk menuju pasar, yakni melalui dua pintu depan serta akses yang di dapatkan pejalan kaki dari permukiman belakang pasar. Pembeli yang berasal dari luar pasar cenderung melewati akses dari pintu kedua di banding pintu pertama. Kedua pintu masuk di depan memiliki satu area parkir dengan sirkulasi menuju pasar di sayap kiri dan kanan bangunan.

Pejalan dan pengendara motor selalu mengakses kedua jalur sirkulasi untuk mencapai bagian dalam pasar. Sedangkan pada bagian depan pasar terdapat tangga yang menghubungkan ke lantai atas bangunan pasar. Oleh karena itu tersedia multiakses pada pasar tradisional ini. Proses kegiatan membeli kebutuhan rumah tangga tidak hanya pada bangunan pasar tersebut, namun juga pada bangunan sekitar pasar yang menjual kebutuhan pokok pembeli. Melewati sirkulasi sebelah kiri dan kanan bangunan pembeli juga bisa mengakses ke bangunan sekitar pasar, sehingga kegiatan pemenuhan kebutuhan tidak hanya di dalam bagunan pasar, namun di sekitar pasar terdapat toko-toko yang menyediakan kebutuhan pembeli. Tidak hanya toko-toko yang berada di sekitar bangunan, namun terdapat juga kios-kios yang memenuhi bagian depan pasar. Kios tersebut menjual kebutuhan tambahan yang diperlukan pembeli, seperti jajanan pasar ataupun kios spesifik lainnya. Kios ini juga mengundang pengendara dari tepi jalan untuk berhenti, sehingga menjadi salah satu kemudahan pengendara di luar pasar untuk membeli kebutuhan tambahan.

Susunan area-area dalam pasar terbagi atas area basah dan area kering. Susunan zonasi kebutuhan bagian dalam cukup teratur dengan beberapa akses 
sirkulasi utama. Pembeli juga dapat menuju lantai atas untuk membeli kebutuhan tambahan seperti gadget ataupun kebutuhan tersier lainnya. Untuk mengkases lantai atas, pembeli harus melalui tangga yang terdapat pada bagian muka bangunan, sehingga tidak dapat di akses melalui dalam bangunan.

1. Akses pencapaian

Akses untuk pencapaian ke area parkir melalui tiga titik jalur menuju pasar, sehingga berpotensi menciptakan ketidakteraturan dalam mencapai lokasi studi kasus.

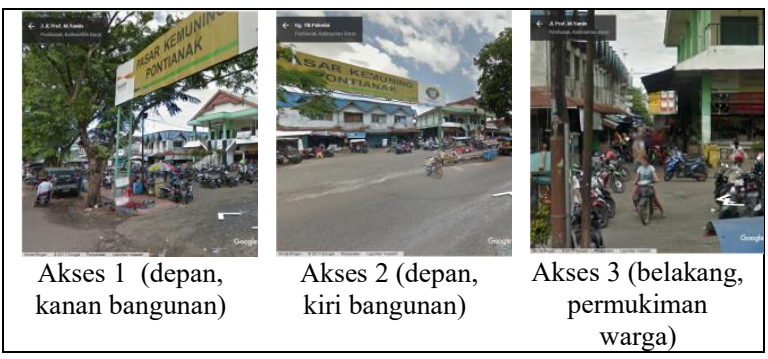

Gambar 2. Akses pengunjung pada eksisting pasar

Titik masuk pengunjung yang pertama terletak pada pintu masuk pertama kali yang ditemukan pengunjung yakni di sebelah kanan bangunan. Kondisi jalur yang tidak terhubung langsung ke bagian utama pasar membuat titik ini digunakan pembeli untuk membeli kebutuhan tambahan yang berada di sekitar area pasar seperti sembako pada bangunan sebelah kiri kanan pasar ataupun kioskios lainnya yang hadir di sekitar pasar. Hal itulah yang membuat jalur pertama ini sangat jarang digunakan pembeli untuk membeli kebutuhan utama yang dipasarkan.

Titik masuk kedua pengunjung berada sebelah kanan bangunan pasar. Selain luasan yang cukup lebar sebagai akses masuk, jalur tersebut terbilang cukup strategis sebab dapat mengakses sirkulasi menuju pasar secara langsung. Namun jalur ini dijadikan juga sebagai jalur keluar masuknya kendaraan, sehingga sering terjadi kapadatan saat pengunjung ramai menuju pasar.

Titik terakhir yang ditemukan dari pergerakan pembeli yaitu melalui jalur belakang bangunan pasar. Jalur ini dilewati oleh para pejalan kaki yag berasal dari area permukima warga. Data ini didapatkan berdasarkan hasil pengamatan serta kedekatannya pasar dengan permukiman warga. Oleh karena itu jalur belakang menjadi salah satu potensi kehadiran pembeli menuju pasar.

Penjelasan ketiga titik sebelumnya menjadi pertimbangan dalam menentukan jalur yang mudah di jangkau oleh pembeli. Masing-masing jalur memiliki kepentingannya sendiri bagi pembeli, karena tidak tersedianya aturan lalu lintas yang baku di sekitar kawasan. Oleh karena itu lebar ataupun sempitnya jalur mempengaruhi kecenderungan akses pembeli, selain itu peletakan jalur yang strategis pada titik tiga membuat pembeli dapat menjangkau pasar lebih baik.

2. Titik simpul sirkulasi

Pada pasar ini juga terdapat beberapa titik pertemuan jalur sirkulasi yang menjadi titik simpul pada akhirnya, yakni pada bagian depan pasar dan belakang pasar. Hal tersebut menjadi salah potensi dalam mengetahui titik-titik keramaian pembeli. Oleh sebab itu titik simpul menjadi salah satu alat dalam penelitian ini untuk melihat titik pertemuan terbanyak manusia dalam kawasan pasar ini.

Terdapat dua titik pada bagian depan, yang memiliki ciri khas sekitar dan fungsi yang sama. Titik tersebut menjadi penentu pembeli dalam menentukan tujuan kedatangannya menuju pasar tersebut, dengan ciri khas memiliki potensi untuk merubah awal kedatangannya menuju pasar serta memiliki fungsi untuk sebagai area yang sering dilalui pembeli karena pertemuan jalur sirkulasi pada eksisting kawasan

Titik simpul 1 sering dilalui pembeli yang berasal dari dalam atau luar kawasan pasar. Dari luar pasar dikarenakan letaknya yang strategis antara pertemuan zona parkir dan zona pasar utama di dalam kawasan. Pengunjung berlalu-lalang pada titik ini, oleh sebab itu juga sebagai potensi dalam menentukan titik keramaian pembeli pasar.

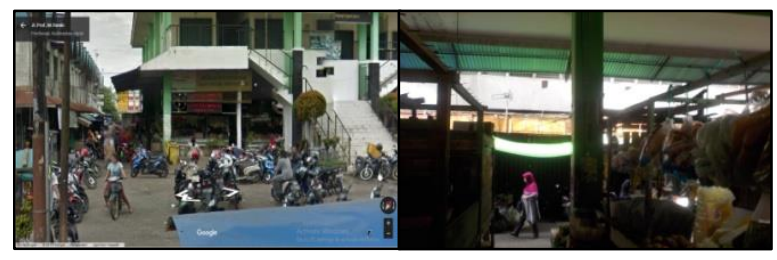

Gambar 3. Titik simpul sirkulasi pasar

Titik simpul 2 terdapat di bagian belakang pasar dengan ciri khas dan fungsi yang berbeda dari titik sebelumnya. Titik pada bagian belakang ini memilki ciri khas yakni pembeli yang berasal dari permukiman sekitar pasar melewati sirkulasi ini. Selain berfungsi sebagai jalur pejalan kaki, jalur ini juga sering dilewati pengendara sepeda motor yang berlalu - lalang di jalur tersebut.

3. Teritori

Teritori pertama yang terbentuk terdapat pada bagian awal akses masuk pasar, dikarenakan pada bagian awal ini dipenuhi oleh kios-kios yang tidak hanya menjadi daya tarik dari dalam kawasan 
pasar, namun menjadi daya tarik dari bagian luar kawasan pasar. Hal-hal yang diperjual belikan juga beragam meliputi hal yang dijual bagi kebutuhan utama pasar serta hal yang dijual berkenaan dengan kebutuhan tambahan pasar maupun kebutuhan di luar pasar. Oleh sebab itu penentuan teritori awal ini juga dapat menunjukan daerah titik keramaian kawasan.

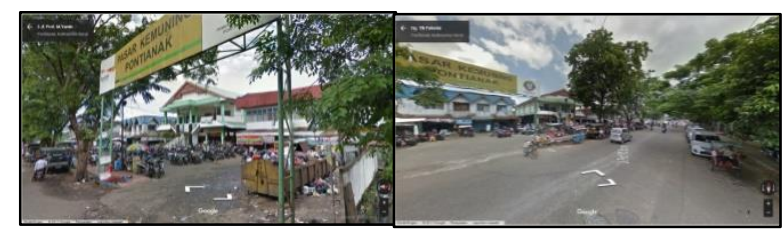

Gambar 4. Area teritori Pasar Kemuning

Terdapat teritori kedua yang cukup berkembang yaitu warung kopi. Warung ini terbentuk karena kebutuhan aktivitas masyarakat pasar yang dilakukan pada pagi hari sehingga selain menyediakan minuman kopi, juga tersedia menu sarapan lainnya yang menjadi daya tarik pengunjung pasar. Pengunjung pasar dapat menikmati sarapan pagi yang tersedia di kios-kios terdekat warung kopi tersebut. Oleh karena itu warung kopi ini juga dapat dinyatakan sebagai area teritori yang berada pada bagian eksisting pasar.

4. Orientasi

Orientasi pada bagian eksisting secara view to site tidak terlalu baik dikarenakan terdapat kios-kios yang mengahalangi pandangan ke bangunan utama pasar, sehingga bangunan pasar tidak mudah di kenal. Pengenalan terhadap pasar dapat ditemui dengan barang dagangan yang dijual pada sekitar pasar tersebut.

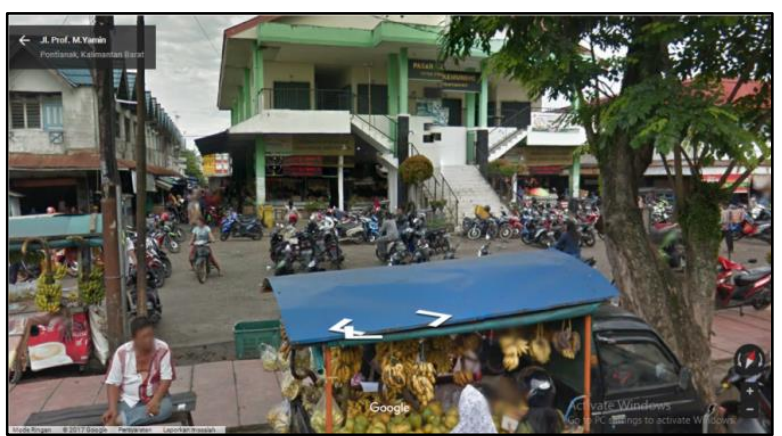

Gambar 5. Orientasi pasar kemuning dari jalan utama

Selain view to site, data view from site juga ditemukan pada pasar ini. Pandangan bangunan terhadap eksisting masih memiliki karakter yang sama dengan sebelumnya dikarenakan terhalang oleh kios-kios pada bagian depan. Selain itu, bangunan memiliki tangga yang terdapat pada bagian depan bangunan, yang digunakan untuk mengakses lantai atas bangunan pasar. Oleh karena itu tangga dan kios-kios menjadi perhatian pandangan terhadap pasar ini.

\section{Pasar Dahlia}

Pasar Dahlia merupakan salah satu pasar tradisional dengan bentuk yang melebar ke samping ataupun horizontal sehingga mudah dikenali oleh pengunjung. Pasar ini merupakan salah satu pasar yang besar, yang berdiri di Pontianak Barat, tepatnya di Jl. H. Rais A. Rachman. Oleh karena itu pasar ini menarik untuk dijadikan sebagai studi kasus penelitian.

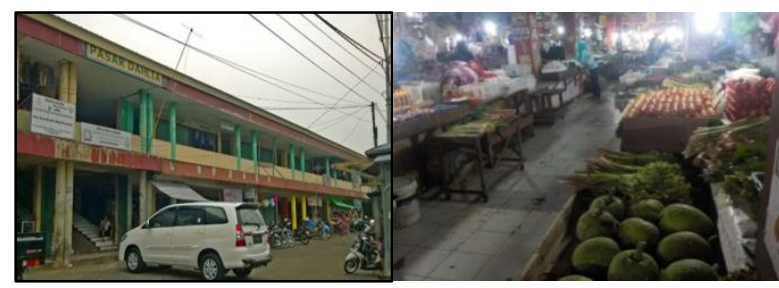

Gambar 6. Suasana Pasar Dahlia

Berdasarkan hasil observasi, bahwa pengunjung dapat memasuki bangunan melalui berbagai akses, baik dari sisi depan maupun sisi lainnya. Pengunjung yang masuk melalui bagian depan rata-rata berasal dari luar kawasan pasar dengan kendaraan bermotor, sedangkan yang melalui akses bagian belakang berasal dari warga sekitar permukiman sekitar pasar dengan berjalan kaki. Pengunjung juga bisa mengakses dari pintu samping bangunan, yaitu dari area terminal dengan rata-rata pengunjung berasal dari pengguna transportasi massal. Oleh sebab itu titik akses pintu masuk bisa dari berbagai arah sesuai kebutuhan pembeli.

Pasar Dahlia berdiri di area kawasan permukiman dengan jalur-jalur akses yang mengelilinginya. Pada bagian sayap kanan bangunan terdapat jalur akses masuk permukiman sekaligus sebagai jalur masuk ke pasar untuk mengunjungi area basah bagi pembeli dengan berjalan kaki atau kendaraan bermotor, sehingga perletakan kebutuhan utama pembeli rata-rata terdapat di sayap kanan ini.

Jalur akses yang berikutnya berasal dari sayap kiri yang berdekatan dengan area terminal kendaraan publik. Pembeli dapat mengakses bagian pasar melalui pintu samping pasar atau melalui teras pasar pada bagian depan ataupun menuju belakang pasar. Jalur akses berikutnya berasal dari belakang pasar yang diperuntukan bagi kawasan permukiman serta pemasok barang menuju pasar. Karakter jalur belakang dan depan memiliki 
karakteristik yaitu multiakses, sehingga pembeli bebas dalam mengkases pasar. Kondisi sekitar eksisting dipenuhi dengan kios-kios bagi kebutuhan pembeli, seperti kios-kios buah, kue, dan lainnya. Kios diletakan pada bagian depan karena banyaknya pengunjung luar yang dapat mengakses langsung kios tanpa masuk ke area pasar. Pertokoan juga terdapat di bagian kawasan pasar yang menjual kebutuhan tambahan dengan pisah massa dari bangunan utama, sehingga kios dan pertokoan tersebut menjadi salah satu kebutuhan pembeli.

Pada bagian dalam bangunan di lantai dasar terdapat pembagian zonasi seperti area basah, kering dan area pertokoan, sedangkan pada lantai atas di khususkan untuk pertokoan sebagai kebutuhan tambahan pasar. Kebutuhan utama pasar dapat di dapatkan pada bagian sayap kanan pasar sedangkan kebutuhan tambahan pasar terdapat pada bagian sayap kiri pasar yang berdekatan dengan kawasan terminal. Untuk menuju lantai atas, pembeli harus mengakses dari tangga bagian depan bangunan. Lantai atas menjual kebutuhan tambahan pasar, namun kondisinya tidak terlalu banyak diisi oleh pembeli, dikarenakan tidak ramai dilalui pembeli. Oleh sebab itu pembeli cenderung lebih banyak ke lantai dasar untuk membeli kebutuhan utama.

1. Akses pencapaian

Pada bagian eksisting pasar, pegunjung memiliki kecenderungan dalam melakukan akses ke bangunan melalui beberapa titik seperti melalui area parkir, area terminal dan jalur belakang area permukiman. Ketiga titik tersebut hadir bagi pembeli dengan latar belakang tempat tinggalnya masing-masing. Pasar Dahlia memberikan kemudahan dengan ketiga akses tersebut, sehingga karakter bangunan yang muncul yaitu memliki pintu multiakses, yang dapat dimasuki pembeli dengan bebas. Oleh sebab itu pembahasan mengenai akses juga menjadi salah satu parameter dalam melihat persebaran pembeli dalam suatu ruang.

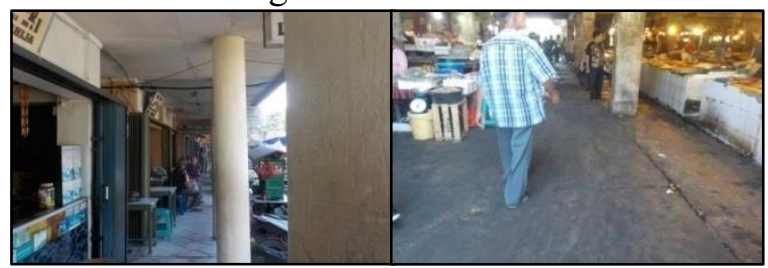

Gambar 7. Akses pada kawasan luar dan dalam pasar

Pasar menyediakan beberapa zonasi sebagai pembagian ruang yakni area kering dan basah pada lantai dasar dan area pertokoan di lantai atas.
Keseluruhan zona memiliki karakteristik dalam pencapaiannya. Jika pembeli ingin menuju ke area basah maka langsung mencapai area di sebelah kanan bangunan dan area kering sebaliknya. Pasar dengan kebutuhan utama yakni kebutuhan konsumsi sehari-hari membuat pembeli menjadi menumpuk ke salah satu sisi bangunan daripada memenuhi kebutuhan tambahan.

\section{Titik simpul sirkulasi}

Pasar Dahlia berdiri di kawasan padat penduduk serta jalan raya yang terbentang di bagian depan bangunan. Di sebelah kanan bangunan terdapat jalur menuju permukiman yang terhubung dengan jalan raya. Terdapat area terminal di sebeleh kiri bangunan yang terhubung denga jalur belakang area permukiman. Oleh karena itu keterhubungan jalur tersubut dapat dipakai sebagai titik simpul sirkulasi dalam penelitian ini.

Di ruang dalam bangunan pasar terdapat berbagai jalur yang saling terhubung karena tipikal bangunan yang multiakses, namun terlihat jalur utama di dalamnya yang dapat menghubungkan pembeli dari titik-titik awalnya yakni dari area parkir, terminal dan jalur permukiman, sehingga jalur utama ruang dalam tersebut dapat dijadikan titik simpul pergerakan.

\section{Teritori}

Kondisi Pasar pada area eksisting dipenuhi oleh kios-kios buah yang terdapat pada bagian luar kawasan Pasar Dahlia. Hal ini menjadi salah satu bagian teritori dikarenakan batas-batas area yang diciptakan penjual bagi kebutuhan pembeli yang tidak hanya dari dalam pasar namun juga untuk para pengguna jalan. Tidak hanya kios di bagian tepi jalan, namun di dalam kawasan sendiri terdapat kios-kios yang menyediaka kebutuhan warga pasarnya seperti warung makan dsb. Oleh karena itu kemunculan kios-kios pada eksisting menjadi salah satu bagian dari parameter teritori.

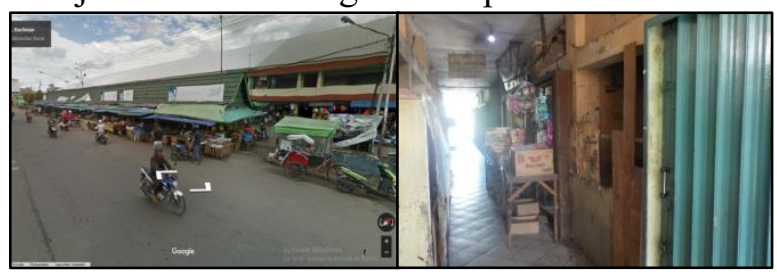

Gambar 8. Teritori pada area luar dan dalam pasar

Ruang-ruang yang terbentuk di dalam pasar juga menjadi salah satu indikasi untuk menemukan area teritori di dalamnya, baik di lantai atas maupun bawah. Di lantai bawah selain area basah dan kering sebagai kebutuhan utama pasar, juga terdapat area kering yang menjual kebutuhan tambahan. Ruang-ruang yang terbentuk secara 
tertutup dan berjarak menjadi salah satu potensi pengembangan area teritori bagi warga pasar. Hal tersebut juga terjadi di lantai atas, dengan pembentukan ruang yang sama pada area keringnya.

\section{Orientasi}

Bentuk bangunan pasar yang melebar cukup menjadikannya sebagai bangunan yang dapat di pandang dari berbagai sudut. Pada bagian eksisting, pandangan terhadap pasar langsung tertuju pada kios-kios yang membentang pada bagian depan pasar, sehingga pengunjung tidak dapat langsung melihat bagian lantai dasar pasar. Hal tersebut cukup mengurangi identitas pasar tradisional sendiri, namun dengan keberadaan lapak buah bisa menjadi pertimbangan mengenai keberadaan pasar. Jika sudah berada di area parkir pada halaman depan pasar, maka dapat melihat tampak pasar dengan ciri multiakses, yakni tersedia lorong ruang bagi sirkulasi ruang dalam pasar.

Sebaliknya jika pandangan pasar dari ruang dalam maka akan terjadi yang seperti sebelumnya. Namun kesan ruang yang cukup gelap dikarenakan bangunan memiliki lantai atasnya, sehingga cahaya kurang masuk pada ruang dalam. Pembeli juga tidak dapat terkoneksi dengan lantai atas jika dilihat dari bawah. Pembeli harus menuju ke ruang luar untuk mengakses serta melihat penjualan di lantai atas.

\section{Analisa Aspek Perilaku}

Metode pengamatan yang dilakukan dalam evaluasi perilaku ini yaitu dengan person center map atau pemetaan berdasarkan pergerakan pengguna. Langkah awal yakni dengan menentukan titik awal pergerakan pembeli pasar disertai jumlah sampel yang akan diambil. Kemudian mengikuti pergerakan pembeli dengan manyatukan aspek perilaku seperti akses pencapaian, titik simpul pergerakan, teritori dan orientasi yang telah didapatkan, sehingga dapat menemukan hasil akhir kesimpulan setiap sample yang diambil.

\section{Titik 1 Pasar Kemuning}

Pada titik 1 terdapat 3 sampel yang diambil dimana arah masuk pengguna berasal dari zona publik, area parkir. Arah masuk ini juga menentukan titik simpul, akses, teritori, dan orientasi pelaku dari satu tempat ke tempat lain dengan mengikuti arah pergerakan pelaku pada sampel. Berikut arah pergerakan dari sampel titik pertama yang dimulai pada area parkir pengunjung pertama, yakni : a. Sampel (1a) titik yang dikunjungi berurutan :(1) Parkir ; (2) Sembako ; (3) Warung Makan ; (4) Buah-buahan ; (5) Parkir.

b. Sampel (1b) titik yang dikunjungi berurutan : (1) Parkir ; (2) Sembako ; (3) Daging ; (4) Bumbu Dapur ; (5) Sembako ; (6) Parkir.

c. Sampel (1c) titik yang dikunjungi berurutan : (1) Parkir ; (2) Warung Makan ; (3) Sembako ; (4) Buah-buahan ; (5) Parkir.

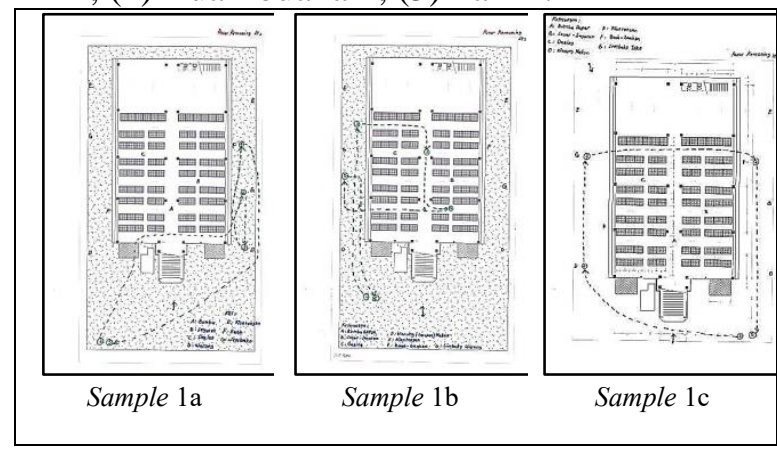

Gambar 9. Mapping titik 1 Pasar Kemuning

Berdasarkan mapping diatas, didapat hasil pengunjung pasar pada titik pertama ini memiliki keberagaman zona yang dikunjungi. Hal tersebut terlihat dari perpindahan yang terjadi di mulai pada titik awal menuju titik selanjutnya hingga titik akhir. Selama berada diantara titik awal dan akhir tersebut, perpindahan pelaku tidak beraturan dalam perpindahannya. Dalam proses ketidakteraturan pergerakan pembeli dari sampel pertama, terdapat beberapa hal kesamaan yang dapat ditemukan yakni adanya area-area kunjungan yang memiliki kesamaan namun berbeda arah pergerakan. Kesamaan area kunjungan dapat mengidentifikasikan sirkulasi yang sering digunakan pembeli, sehingga melalui hal tersebut dapat mendapatkan kesimpulan dari parameter yang akan digunakan.

Hasil data yang telah dikumpulkan terdapat titik yang selalu di lewati pembeli yaitu pada area sembako dan buah-buahan, jika pembeli melalui titik awal aktivitas dari area parkiran kedua. Perletakan area sembako dan buah-buahan berada pada tepian sirkulasi samping kiri dan kanan bangunan. Hal tersebut menjadi area kunjungan yang pasti dilalui pembeli karena jalur tersebut menjadi jalur sirkulasi utama pejalan kaki yang berkunjung ke pasar. Oleh karena itu sirkulasi pejalan kaki pada kiri dan kanan bangunan dapat dinyatakan sebagai akses utama menuju ruang dalam pasar.

Titik simpul pergerakan luar dari pengamatan titik pertama ini terletak pada jalur sirkulasi kiri dan kanan bangunan jika diamati berdasarkan kondisi 
eksisting pasar. Hal tersebut dikarenakan jalur ini sebagai penghubung antar jalur depan dan belakang pasar. Berdasarkan kondsi ruang dalam pasar, titik simpul dapat ditemukan pada pertemuan sirkulasi secara vertikal dan horizontal di dalamnya. Pasar Kemuning memiliki multiakses untuk menuju ruang dalam, sehingga jalur simpul tersebut sering dilalui pembeli daripada jalur lainnya. Namun jalur secara vertikal harus terhalang oleh tangga yang terdapat di bagian depan bangunan sehingga pengunjung harus melalui sikulasi samping kiri dan kanan bangunan pasar untuk mengkases bagian ruang dalam pasar. Oleh sebab itu titik simpul secara horizontal dapat dijadikan pertimbangan sebagai jalur pintu utama menuju pasar.

Akses pencapaian pada titik ini, jika pembeli melalui area parkir sebagai titik awal cenderung bergerak melalui jalur sirkulasi kiri dan kanan bangunan. Hal ini terjadi karena suasana halaman depan dipenuhi dengan parkiran kendaraan, selain itu terdapat tangga untuk akses menuju lantai atas yang terdapat pada bagian muka depan bangunan. Kondisi ruang dalam pasar dengan perbedaan antara area basah dan kering juga mempengaruhi pergerakan pembeli di dalamnya. Pembeli cenderung melewati sirkulasi yang lebar untuk perpindahan antar satu tempat ke tempat lainya. Sirkulasi yang mempunyai kriteria tersebut adalah sirkulasi vertikal dan horizontal pada bagian tengah pasar. Oleh sebab itu pembeli cenderung memerlukan akses yang cukup lebar untuk memudahkan pergerakannya.

Pada titik ini terdapat beberapa area teritori yang digunakan warga pasar yakni kios-kios, warung kopi dan jalur sirkulasi. Dengan sampel pertama pengunjung masuk melalui jalur masuk utama sehingga menemukan kios-kios tersebut. Kioskios ini juga mempengaruhi ruang gerak pembeli khususnya bagi pengendara motor yang hendak memarkirkan kendaraannya. Teritori yang terbentuk berikutnya yakni jalur sirkulasi bagian kiri dan kanan pasar. Selain dilalui pejalan kaki, jalur ini juga dilewati oleh pengendara motor yang hendak mengakses permukiman belakang pasar.

Kecenderungan orientasi ketiga sampel pada titik ini, pandangan pembeli menuju site menggunakan sirkulasi kiri dan kanan karena tidak dapat melewati bagian depan bangunan sebab terdapat tangga yang menghalanginya. Begitu juga sebaliknya, jika pandangan pembeli dari dalam bangunan.

2. Titik 2 Pasar Kemuning

Berikut merupakan penjelasan pergerakan 3 sampel di titik 2, yang dimulai dari arah area permukiman belakang bangunan pasar, yakni :

a. Sampel (2a) titik yang dikunjungi berurutan

:(1) Permukiman ; (2) Warung Makan ; (3)

Klontongan ; (4) Buah-buahan ; (5) Sembako

; (6) Permukiman.

b. Sampel (2b) titik yang dikunjungi berurutan :

(1) Permukiman ; (2) Sembako ; (3) Sayuran

; (4) Bumbu Dapur; (5) Permukiman.

c. Sampel (2c) titik yang dikunjungi berurutan :

(1) Permukiman; (2) Buah-buahan ; (3)

Daging ; (4) Bumbu Dapur ; (5) Warung Kue

; (6) Permukiman

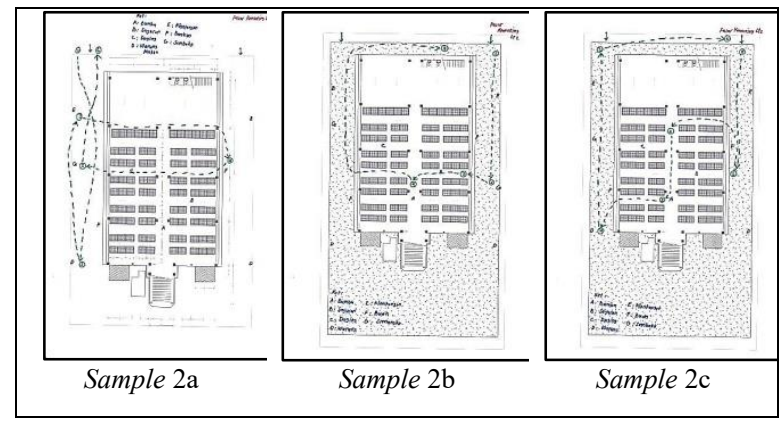

Gambar 10. Mapping titik 2 Pasar Kemuning

Ketiga sampel pembeli yang masuk dari arah belakang bangunan berasal dari area permukiman warga. Pembeli menggunakan sirkulasi untuk mengakses dengan berjalan kaki sehingga jalur sebalah kiri dan kanan secara aktif digunakan oleh pembeli, sehingga dapat jalur berlakang berhubungan dengan akses kiri kanan bangunan yang membentuk simpul.

Pertokoan tidak hanya terbentuk di bagian kiri dan kanan, namun juga terbentuk pada area belakang pasar. Hal tersebut menjadi potensi pembeli untuk memenuhi kebutuhan utama juga pada area belakang pasar. Oleh sebab itu pertokoan di bagian belakang juga menjadi salah satu potensi terbentuknya area teritori terdekat pasar.

Orientasi pembeli terhadap bangunan, jika tampak dari belakang maka akan menemukan beberapa pertokoan yang menjual kebutuhan utama seperti yang terdapat di pasar. Hal tersebut menjadi sebuah pilihan bagi pembeli untuk memenuhi kebutuhan utamanya khususnya yang berkisaran pada kawasan pasar sendiri. Pada saat di ruang dalam pasar, pembeli yang berasal dari belakang melihat sirkulasi horizontal sebagai penghubung utama untuk sampai ke lapak-lapak yang tersedia. Oleh sebab itu pembeli yang berasal dari belakang akan menemukan banyak pilihan untuk memenuhi kebutuhan utamanya 


\section{Titik 1 Pasar Dahlia}

Pada kasus pasar kedua ini, juga mengamati dua titik pergerakan pembeli, setiap titik diambil 3 sampel dan dilakukan person center map. Berikut merupakan pergerakan sampel yang dimulai pada area parkir pengunjung, yakni :

a. Sampel (1a) titik yang dikunjungi berurutan

:(1) Parkir ; (2)Warung Makan ; (3) Sayuran

; (4) Buah-buahan ; (5) Parkir.

b. Sampel (1b) titik yang dikunjungi berurutan :

(1) Parkir ; (2) Bumbu Dapur ; (3) Sembako ;

(4) Sayuran; (5) Warung Makan ; (6) Parkir.

c. Sampel (1c) titik yang dikunjungi berurutan :

(1) Parkir; (2) Daging ; (3) Sayuran ; (4)

Bumbu Dapur ; (5) Parkir.

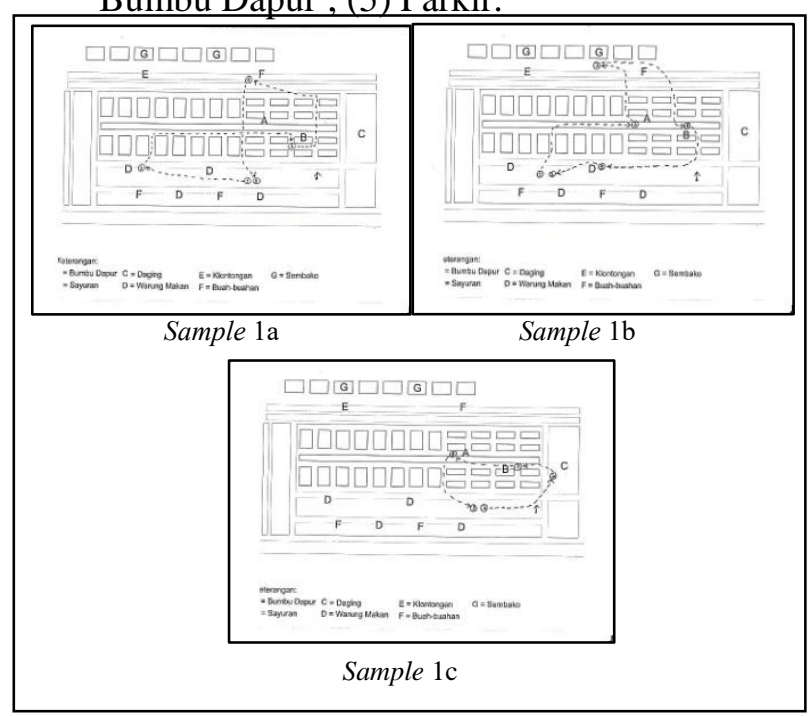

Gambar 11. Mapping titik 1 Pasar Dahlia

Jika pengunjung berasal dari luar kawasan pasar, maka ada beberapa titik yang selalu di kunjungi, terlihat pada ketiga sampel di atas yakni rumah makan, sayuran dan buah. Jalur utama yang dilewati pembeli yakni melalui teras pasar serta jalur utama ruang dalam yang memisahkan antara area kering dan area basah. Hal tersebut terjadi karena pembeli dari luar cenderung memenuhi kebutuhan utama terlebih dahulu sebelum kebutuhan tambahan yakni daging, sayur, dsb. Oleh sebab itu penelusuran pembeli menggunakan beberapa parameter perilaku menjadi penting agar dapat mengetahui persebaran merata yang terjadi di pasar.

Pada sampel titik pertama Pasar Dahlia, titik simpul pergerakan pembeli terdapat pada bagian eksisting pasar. Pengujung dari luar kawasan yang melalui jalan utama cenderung langsung mengakses sirkulasi yang menghubungkan ke area basah dan kering pasar sebagai kebutuhan utama. Selain berasal dari area parkir, ada juga pembeli yang berasal dari jalur akses langsung melalui jalan kecil ke arah permukiman, sehingga bisa langsung mendapatkan barang yang diperlukan pembeli. Oleh karena itu titik simpul terjadi pada jalan-jalan yang menghubungkan pada bagian kanan bangunan pasar.

Jika dilihat dari ruang dalam bangunan pasar, maka pembeli cenderung melewati sirkulasi dalam utama yang saling terhubung menjadi jalur simpul antara area basah dan kering. Namun, karena pasar terbangun atas multiakses, sehingga pembeli melalui sirkulasi kecil antar lapak penjual sebelum melewati jalur utama, sehingga jalur utama dianggap sebagai titik pandang pembeli untuk menuju ke area pasar yang dibutuhkan.

Pada bagian kanan bangunan pembeli cenderung melakukan akses dan penjangkauannya langsung ke area basah ataupun kering. Terlihat pada sampel, baik pembeli yang parkir di bagian kiri ataupun tengah, langsung menuju bagian tersebut untuk memenuhi kebutuhanya, sehingga zona di sebelah kiri bangunan cenderung lebih sepi daripada di sebelah kanannya.

Sepinya zona kiri dibandingkan zona kanan yang menjual kebutuhan tambahan pasar ini, membuat munculnya potensi untuk membangun batasan teritori pelaku pasar. Pemecahan ruang satu dengan ruang lainnya menciptakan ruang antara didalamnya, sehingga ruang ini dapat dimanfaatkan bagi beberapa pelaku pasar dan menjadi batas teritorinya. Oleh sebab itu teritori kuat terjadi pada bagian sisi kiri bangunan pasar dahlia ini.

Pada area eksisting pembeli cenderung tidak dapat memandang lantai bawah pasar. Hal ini dikarenakan penciptaan area teritori kembali pada jalur pejalan kaki pasar dengan kios-kios yang tersebar di luarnya, sehingga pembeli cenderung melewati sirkulasi kanan bangunan yang langsung terhubung ke area utama pasar daripada melewati kios pada bagian tengah serta kebutuhan tambahan pasar pada bagian kiri bangunan. Orientasi bangunan sangat mudah dikenali dari arah jalan utama karena bentuk bangunan yang memanjang.

\section{Titik 2 Pasar Dahlia}

Berikut merupakan penjelasan pergerakan sampel titik kedua, yang dimulai dari arah area permukiman belakang pasar, yakni :

a. Sampel (2a) titik yang dikunjungi berurutan :(1) Permukiman ; (2)Sembako; (3) Bumbu Dapur ; (4) Daging ; (5) Bumbu Dapur ; (6) Permukiman. 
b. Sampel (2b) titik yang dikunjungi berurutan : (1) Permukiman ; (2) Klontongan; (3) Daging ; (4) Klontongan; (5) Permukiman.

c. Sampel (2c) titik yang dikunjungi berurutan :

(1) Permukiman ; (2) Warung Makan ; (3)

Sayuran ; (4) Sembako ; (5) Klontongan ; (6) Permukiman

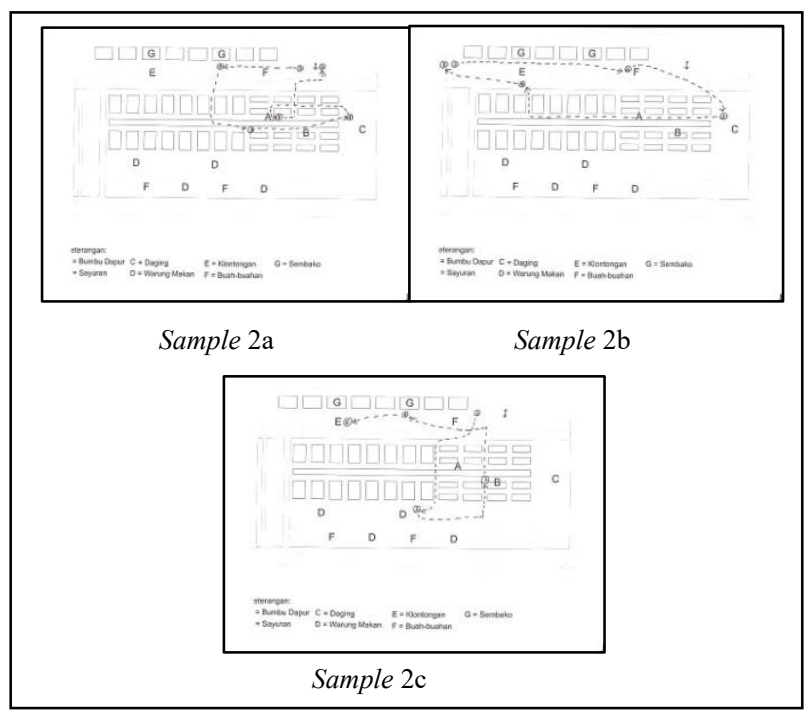

Gambar 12. Mapping titik 2 Pasar Dahlia

Pada ketiga sampel titik ini, pelaku berasal dari jalur belakang area permukiman. Pelaku yang ditemukan berdasarkan survei berasal dari area permukiman dan pejalan kaki dari lingkungan sekitar. Pelaku menggunakan jalur belakang ataupun mengakses langsung ke dalam pasar melalui multiakses pada bangunan pasar.

Oleh karena itu jalur belakang digunakan pelaku dari area permukiman untuk menuju bangunan pasar. Jalur belakang terhubung dengan jalur permukiman warga, sehingga dapat dinyatakan sebagai titik simpul. Jalur ini digunakan juga sebagai akses untuk mencapai lapak-lapak di ruang dalam pasar, melewati jalur utama pasar meskipun pasar terdiri atas multiakses di dalamnya. Oleh sebab itu sirkulasi luar belakang bangunan terhubung dengan sirkulasi dalam pasar. Pengunjung pasar yang berasal dari belakang permukiman cenderung langsung mengakses area basah dan kering pasar untuk mengisi kebutuhan utama pembeli, sehingga pengunjung jarang melewati area kering yang menjual kebutuhan tambahan. Berdasarkan data di atas, pelaku melewati area kering tersebut dengan sirkulasi utama pasar untuk menuju area basar kering yang menjual kebutuhan utama pembeli.

Pada bangunan belakang pasar terdapat lingkungan pertokoan yang menjual barangbarang dagangan bagi pembeli, sehingga kebutuhan utama tidak hanya tersedia di ruang dalam pasar namun terdapat juga di ruang luar pasar. Lingkungan pertokoan ini menjadi salah satu potensi area teritori sekitar kawasan pasar. Pembeli juga cenderung melewati jalur belakang untuk membeli kebutuhan utama tersebut. Oleh sebab itu sirkulasi belakang dapat digunakan pembeli baik mengakses bangunan pasar maupun pertokoan.

Orientasi pembeli terhadap bangunan pasar terlihat jelas tampak bangunan pasar yang memanjang dengan multiakses menuju lantai bawah. Pembeli pasar yang berasal dari belakang dapat mengkases lantai atas melalui tangga belakang, dan tidak bisa langsung dari ruang dalam pasar sendiri. Oleh sebab itu pandangan dari ruang dalam lantai bawah tidak terkoneksi dengan lantai atas.

\section{Matrik Hasil Pembahasan}

Untuk memudahkan merumuskan hasil analisa dari kedua kasus pasar, maka dibuat matrik pembahasan sebagai berikut :

Tabel 1. Matrik hasil pembahasan evaluasi perilaku pasar

\begin{tabular}{|c|c|c|c|}
\hline \multicolumn{2}{|c|}{ PASAR KEMUNING } & \multicolumn{2}{|c|}{ PASAR DAHLIA } \\
\hline Eksternal & Internal & Eksternal & Internal \\
\hline \multicolumn{4}{|c|}{ Akses pencapaian } \\
\hline $\begin{array}{l}\text { Area Pejalan Kaki } \\
\text { dijadikan sirkulasi } \\
\text { utama dibandingkan } \\
\text { kendaraan motor atau } \\
\text { adanya pembatasan. }\end{array}$ & $\begin{array}{l}\text { Tampak Samping } \\
\text { sebelah kiri-kanan } \\
\text { bangunan menerapkan } \\
\text { One Gate System agar } \\
\text { persebaran teratur. }\end{array}$ & $\begin{array}{l}\text { Multifungsi akses } \\
\text { membuat pembeli } \\
\text { dapat meyebar secara } \\
\text { tidak merata pada } \\
\text { ruang dalam kerena } \\
\text { dapat mengakses } \\
\text { bagian ruang luar } \\
\text { pasar tanpa melalui } \\
\text { sirkulasi utama ruang } \\
\text { dalam }\end{array}$ & $\begin{array}{l}\text { Ketidakseimbangan } \\
\text { perletakan zonning } \\
\text { area basah dan kering } \\
\text { di bagian samping } \\
\text { membuat pembeli } \\
\text { lebih cenderung ke } \\
\text { area tersebut daripada } \\
\text { kebutuhan tambahan } \\
\text { lainnya }\end{array}$ \\
\hline
\end{tabular}


Tabel 1. Lanjutan

Pembahasan : (multiakses)
Pergerakan pembeli cenderung melalui sisi kiri
dan kanan bangunan sehingga dapat
menyediakan sistem satu pintu bagi pembeli.

Pembahasan : (multiakses)

Persebaran pergerakan pembeli dapat merata di bagian ruang dalam dengan menggunakan sistem satu pintu, sehingga pembeli dapat menentukan fokus pergerakan.

\begin{tabular}{|c|c|}
\hline & \\
\hline $\begin{array}{l}\text { Area Pejalan Kaki di } \\
\text { sebelah kiri-kanan } \\
\text { bangunan di aktifkan. } \\
\text { Serta kios-kios pada } \\
\text { bagian depan } \\
\text { bangunan dilakukan } \\
\text { pengaturan lebih } \\
\text { lanjut. }\end{array}$ & $\begin{array}{l}\text { Sirkulasi utama ruang } \\
\text { dalam pasar sisi } \\
\text { horizontal dijadikan } \\
\text { sebagai jalur utama. }\end{array}$ \\
\hline \multicolumn{2}{|c|}{$\begin{array}{l}\text { Pembahasan : (sirkulasi) } \\
\text { Pergerakan pembeli khususnya pejalan kaki } \\
\text { dapat meggunakan sirkulasi sebelah kiri dan } \\
\text { kanan bangunan yang tidak dilewati kendaraan } \\
\text { bermotor, sehingga bangunan sekitar pasar } \\
\text { dapat berkontribusi bagi kebutuhan pembeli. } \\
\text { Sirkulasi dalam bangunan dapat di } \\
\text { maksimalkan dengan menyesuaikan pergerakan } \\
\text { pembeli awal yakni dari sebelah kiri dan kanan } \\
\text { bangunan. }\end{array}$} \\
\hline
\end{tabular}

\section{ul Sirkulasi}

Kebutuhan ruang

untuk menjual buah-

buahan dapat

dilakukan dalam

bangunan pasar

dengan pemindahan

lapak di bagian eksisting

Pembahasan : (sirkulasi)

Pembeli dapat memanfaatkan teras bagian luar pasar sebagai jalur sirkulasi karena bentuk bangunan yang melebar sehingga dapat menyesuaikan akses pembeli baik dari depan dan belakang bangunan.

Penataan bagian ruang dalam pasar dapat dilakukan dengan menyesuaikan jalur utama pasar yang dilewati pembeli, secara khusus agar tidak terjadi pemecahan akses pada ruang dalam.
Pada bagian ruang dalam pasar, pembeli cenderung melewati sirkulasi vertikal horizontal utama, namun juga ada yang melalui teras pasar

\section{Teritori}

\begin{tabular}{l|l} 
Pembeli disediakan & Sirkulasi utama ruang \\
jalur pejalan kaki & dalam difungsikan \\
khusus yang tidak & sebagai jalur menuju \\
dilewati kendaraan & lapak pasar yang telah \\
bagi pertokoan sekitar & diatur areanya. \\
pasar. &
\end{tabular}

Pembahasan : (kios-kios)

Perletakan kios pada bagian depan bangunan hanya diperlukan bagi pembeli luar, sehingga penataan lebih lanjut dapat membuat pergerakan pembeli bagian dalam lebih efektif.

\begin{tabular}{|c|c|}
\hline $\begin{array}{l}\text { Perpindahan lapak } \\
\text { buah sangat } \\
\text { berpotensi ke bagian } \\
\text { dalam pasar dengan } \\
\text { persebaran area yang } \\
\text { merata. }\end{array}$ & $\begin{array}{l}\text { Persebaran zoning } \\
\text { area penjualan di } \\
\text { dalam pasar dengan } \\
\text { memperioritaskan } \\
\text { kebutuhan utama. }\end{array}$ \\
\hline \multicolumn{2}{|c|}{$\begin{array}{l}\text { Pembhasan : (kios-kios) } \\
\text { Kios-kios buah berpotensi untuk diletakan pada } \\
\text { bagian dalam bangunan yang belum berfungsi } \\
\text { sehingga dapat menyelesaikan persebaran } \\
\text { pembeli baik di bagian dalam dan luar pasar. }\end{array}$} \\
\hline \multicolumn{2}{|c|}{ entasi } \\
\hline $\begin{array}{l}\text { View to site jika dari } \\
\text { tampak depan sangat } \\
\text { terlihat dengan } \\
\text { kehadiran pedagang } \\
\text { buah, sehingga dapat } \\
\text { di pertimbangkan. }\end{array}$ & $\begin{array}{l}\text { View dari lantai bawah } \\
\text { ke atas tidak } \\
\text { terkoneksi. Sebaiknya } \\
\text { pembeli dapat melihat } \\
\text { keseluruhan zoning } \\
\text { area pasar }\end{array}$ \\
\hline \multicolumn{2}{|c|}{$\begin{array}{l}\text { Pembahasan : (hubungan antar lt.1 dan lt.2) } \\
\text { Lantai } 2 \text { yang jarang dikunjungi pembeli karena } \\
\text { tidak menemukan koneksi antar lantai } \\
\text { bangunan dari dalam pasar. }\end{array}$} \\
\hline
\end{tabular}

dari luar bangunan namun bagian dalam bangunan sebaliknya, sehingga diperlukan suatu konektivitas antar lantai. 


\section{KESIMPULAN}

1. Evaluasi Purna Huni untuk pengukuran kinerja atau performansi bangunan dengan aspek perilaku sangat efektif diterapkan bagi kedua pasar tradsional ini. Adapaun pemecahan tiap masalah dapat dibuktikan dengan pergerakan tiap pembeli dengan metode person center mapping serta dengan menganalisa parameter aspek perilaku ; akses pencapaian, titik simpul pergerakan, , area teritori, dan orientasi, sehingga kinerja bangunan pasar dapat semakin optimal.

2. Pasar Kemuning dan Pasar Dahlia masingmasing memiliki ciri khas yang sama meskipun dengan lokasi yang berbeda. Kedua pasar memiliki lantai atas yang kurang produktif hal ini terjadi karena pembeli tidak memiliki koneksi baik secara pandangan dengan bagian lantai bawah. Hal tersebut menimbulkan pembeli hanya cenderung memenuhi kebutuhan utama daripada kebutuhan tambahan. Oleh sebab itu diperlukan konektivitas antar dua kebutuhan baik dari lantai atas maupun lantai bawah bangunan.

3. Perletakkan kios-kios pada bagian luar bangunan pasar menyebabkan ketidakseimbangan persebaran pembeli dalam pasar dan menimbulkan penurunan kualitas kawasan pasar secara langsung. Pasar Kemuning sudah menyediakan

4. bangunan sekitar sebagai tempat pemenuhan kebutuhan pembeli, sedangkan Pasar Dahlia memiliki potensi pada ruang-ruang bagian dalam yang dapat diaktifkan kembali untuk para penjual buah yang berada di kios luar, sehingga kontribusi untuk peningkatan produktivitas pasar dapat terjadi di dalamnya.

5. Pengoptimalan suatu fungsi ruang dapat terjadi bila tidak terjadi persebaran pembeli yang kurang merata pada bagian dalam bangunan. Hal tersebut terjadi karena kesedian akses mutifungsi pada kedua pasar tersebut, sehingga pengunjung memiliki kebebasan dalam mengakses salah satu tempat berdasarkan kebutuhannya.

\section{DAFTAR PUSTAKA}

Chikezie. Eke, Clinton. Aigbavboa, and Wellington. Thwala. (2013), An Exploratory
Literature Review of Post Occupancy Evaluation. International Conference on Civil and Environmental Engineering (CEE'2013), Johannesburg (South Africa), Nov. 27-28

Haryadi, Setiawan. (1995), Arsitektur Lingkungan dan Perilaku, Jakarta : Pengembangan Pusat Studi Lingkungan, DIKTI

Keputusan Menteri Perindustrian dan Perdagangan Nomor 23/MPP/KEP/1/1998 tentang Lembaga-Lembaga Usaha Perdagangan

Khalil, Natasha. (2008), Performance Analysis of Government and Public Buildings via Post Occupancy Evaluation. Journal of Social Science Asian, Graduate Centre Department, Faculty of Architecture Planning and Surveying, University Technology MARA (UiTM) Shah Alam, Malaysia, Volume 4 no $9: 103$

Laurens, Joyce M. (2004), Studi Perilaku Lingkungan, Surabaya: Universitas Kristen Petra

Snyder, James C and Catanese, Anthony J. (1984), Pengantar Arsitektur. Erlangga: Jakarta.

Sukriswanto, Ucang. (2012), Analisa Kelayakan Revitalisasi Pasar Umum Gubug Kabupaten Grobogan. Tesis tidak diterbitkan, Program Studi magister Teknik Sipil, Universitas Diponegoro Semarang

Zimring, C.M. and Reizenstein, J.E. (1980), Post Occupancy Evaluation : An Overview, Environment and Behavior, 12, 429-451. 